\title{
EDITORAL DOSSIÊ CIDADE DO SÉCULO XVIII
}

\author{
Rodrigo Almeida Bastos \\ Universidade Federal de Santa Catarina \\ rodrigobastos.arq@gmail.com
}

Nas histórias da arte, da arquitetura e da cidade, toda denominação que se caracterize por uma identificação temporal ou estilística corre o risco de ser generalista e superficial. Assim, há algumas décadas, temos consciência dos proveitos mas também dos limites de algumas classificações como: a "cidade medieval", a "cidade ideal", a "cidade barroca", a "cidade iluminista" etc., tanto pelo que resta excluído do nome quanto pelo que pode vir a residir dentro dele, quase sempre arbitrariamente. Acrescente-se, ainda, que uma denominação geralmente não oferece uma identidade semântica homogênea ou unívoca, uma concordância absoluta de entendimento para aqueles que se interessam por ela - essa cidade reificada por um epíteto ou pelo número de um século que, a bem da verdade e do rigor, só tem começo e fim nos calendários.

Advertência epistemológica necessária. Nada mais complexo e irredutível que a cidade, em que tantas são suas ciências, suas geografias, seus contextos, seus olhares. Assim, este Dossiê sobre a cidade do século XVIII buscou se esquivar daqueles lugares metodológicos tradicionais, conquanto tenham sido fundamentais para a historiografia há mais de um século. Em vez de se encerrar no nome, ilusoriamente satisfeito pela comodidade positiva de uma classificação, procuramos nos abrir para uma diversidade representativa de abordagens, abrigadas sob um arco temporal notoriamente organizacional; sobretudo em se tratando do século XVIII, um período marcado por transformações em todos os âmbitos mais relevantes da civilização: ciência, política, religião, filosofia, estética, artes, tecnologia etc., transformações essas que não começaram nem terminaram dentro de suas fronteiras temporais. Ademais, as dinâmicas constitutivas da cidade compreendem processos de longa duração, principalmente antes da modernização industrial; o que implica, muitas das vezes, ter que reconhecer e que considerar modelos, práticas e conceitos vigentes muito antes de seu tempo estrito ou que dele se tornaram contemporâneos por sua eficácia e sua adequação.

Desta feita, um dossiê sobre a cidade do século XVIII não se fez apenas oportuno, quanto também desafiador. Poucos períodos da história apresentam cidades e pensamentos

(c) Urbana: Rev. Eletrônica Cent. Interdiscip. Estud. Cid. Campinas, SP v.10, n.1 [18] p.01-03 jan./mai. 2018 
sobre a arte de edificá-las tão diversos quanto o período em tela. Isto nos conduziu a uma premissa: mostrar a diversidade desse conjunto de empresas e histórias setecentistas, congregando pesquisas recentes e reflexões que nos permitissem almejar não o esgotamento de sua representação, mas a evidência de sua rica e imensa complexidade.

Nas últimas décadas, a história da cidade no século XVIII recebeu uma contribuição bastante significativa. Várias foram as circunstâncias desse crescimento, especialmente em nosso ambiente científico: o crescimento e a consolidação da pós-graduação em áreas de arquitetura e urbanismo, história, geografia etc., a realização frequente dos Seminários sobre história da cidade e do urbanismo (SHCU) desde 1990, as pesquisas sobre a arte e a cidade dita "barroca" nos anos de 1980 e 1990, impulsionadas pela Revista Barroco e também pela tradição das pesquisas do IPHAN sobre a arquitetura e as cidades coloniais, a comemoração das navegações e expansões portuguesas (SCDP), em que se empreenderam várias pesquisas e publicações individuais e coletivas, uma conexão maior e mais efetiva entre pesquisadores do Brasil, da Europa e também de outros países americanos, uma maior acessibilidade a arquivos e documentos históricos, tratados, atas, termos, ordens régias, mapas e desenhos, aqui e alhures.

Favorecidas por essas circunstâncias, muitas pesquisas recentes dialogaram com estudos anteriores sobre a urbanização setecentista luso-brasileira, como aqueles de Murillo Marx, Nestor Goulart Reis Filho, Sylvio de Vasconcellos, Paulo Santos e outros. Durante o século XX, passamos de um diagnóstico inicial de "desleixo", "espontaneidade", "irregularidade" e "desordem", assim como se encontravam nas teorias de Sérgio Buarque de Holanda, Robert Smith e seguidores, para uma compreensão que não apenas reviu e apontou críticas a esses diagnósticos, como também soube reconhecer virtudes várias de conveniência, adequação, decoro, formosura, comodidade, ordem e regularidade correspondentes ao tempo mesmo daquelas cidades. E conseguimos, afinal, superar uma compreensão histórica que dependia de uma visão moderna de desenho e "planejamento urbano" assentes quase que exclusivamente em traçados geométricos estritamente retilíneos.

Assim, chegamos ao século XXI podendo confirmar virtudes de uma escola portuguesa (ou já luso-brasileira) de urbanismo que primava antes por "princípios", nas palavras de Eduardo Horta Correia, do que por regras e modelos fixos distanciados das circunstâncias efetivas de ocupação e assentamento; uma escola povoadora de construção e participação coletivas, dinamizada por procedimentos e preceitos que eram levados a cabo por uma rica e diversa coleção de "agentes povoadores: desde letrados que haviam frequentado as aulas de arquitetura e engenharia militar na metrópole e na colônia, passando por oficiais da 
administração pública como governadores, vereadores, juízes, arruadores do conselho, ouvidores etc., até os mestres e artífices que compartilhavam saberes e práticas consolidados em costumes construtivos seculares - todos eles dedicados, entre outras providências públicas, ao aumento e à conservação de povoações.

Há algum tempo, a Revista Urbana vem organizando uma série de dossiês temáticos destinados a contemplar a complexidade de pensamentos, práticas, problemas, projetos e princípios que nortearam a compreensão e a construção das cidades. Um empreendimento admirável, facilitado pelo acesso eletrônico com o qual se disponibiliza a revista, que vem dando frutos importantes para a ciência do urbanismo em nossos ambientes de discussão.

Este novo dossiê traz textos diversos e muito interessantes para a compreensão das cidades no século XVIII. Há aqueles que se dedicaram a objetos urbanos muito precisos, como a povoação de Cabo Verde, no artigo de Carolina de Almeida e Renata Baesso, ou aos projetos de reforma e aumento da cidade de Madri, no texto de Concepción Aparicio; houve quem reavivasse a discussão com objetos tradicionais: historiadores, como no texto de Sabrina Melo sobre Robert Smith, ou conjuntos urbanos de fato, como no artigo de Simona Costa sobre as vilas de Minas Gerais; ou apontasse renovações metodológicas a partir de fontes primárias como as das décimas urbanas e dos censos, como na pesquisa coletiva de Beatriz Bueno, Nádia de Moura, Esdras Arraes e Diogo Borsoi, cotejando-as em várias povoações. Rodrigo Baeta recuperou a discussão sobre a cidade hispano-americana e Sérgio Fagerlande contemplou a vida urbana em torno às casas de ópera na cidade do Rio de Janeiro.

Como era nosso intuito, desde a chamada de trabalhos, o dossiê que o leitor tem agora à sua disposição é uma amostragem rica e representativa do inelutável processo de compreensão da urbanização setecentista, um dos meios possíveis de se habitar a história e também aquelas cidades. Oxalá seja o primeiro de muitos. Boa leitura!

(c) Urbana: Rev. Eletrônica Cent. Interdiscip. Estud. Cid. Campinas, SP V.10, n.1 [18] p.01-03 jan./mai. 2018 